\title{
PROBLEMATIC ISSUES OF THE DEVELOPMENT OF MODERN DUEL-USE TECHNOLOGIES
}

Oleksandr SHKATULA

shkatula_a_p@ukr.net

Yurii KORNIICHUK

korniy.yg@gmail.com

Natalya PETRENKO

natapni@ukr.net

Korolov Zhytomyr Military Institute, Ukraine

\begin{abstract}
On the ground of the analysis of the development of the indigenous innovation system, this paper substantiates the necessity of updating and modernizing the technological base for the production of dual-use items, aimed at increasing the economic potential and ensuring the political independence of Ukraine. Furthermore, the paper presents the problems and ways of improving the production of dual-use products. The special aspects of legislation on protection of the results of intellectual activity of dual-use products are scrutinized. The author also presents the results of the analysis of normative legal acts regulating protection of the results of military, special and dual use intellectual activity in Ukraine. Streszczenie: $W$ artykule, opartym na analizie rozwoju krajowego systemu innowacji, uzasadniona jest konieczność aktualizacji i modernizacji bazy technologicznej do produkcji produktów podwójnego przeznaczenia, która ma na celu zwiększenie potencjału gospodarczego kraju i zapewnienie politycznej niezależności Ukrainy. Przedstawiono problemy $i$ sposoby poprawy produkcji produktów podwójnego zastosowania. Artykuł dotyczy cech ochrony prawnej wyników działalności intelektualnej produktów podwójnego zastosowania. Przeprowadzono analizę normatywnych aktów prawnych regulujących ochronę wyników działalności intelektualnej o charakterze wojskowym, specjalnym i podwójnym na Ukrainie.
\end{abstract}

Keywords: dual-use products, innovations, technologies, military-industrial complex

Stowa kluczowe: : produkty podwójnego zastosowania, innowacje, technologie, kompleks obronno-przemystowy

\section{INTRODUCTION}

Ukraine has adopted a market economy. It means that enterprises themselves must find necessary investment for science-based industry, that is, to create applied science, technology, equipment, and develop production out of profits. Ukraine does not possess the means that the USSR used to have. Reforms and liberalization of prices have actually deprived the country of its working capital. Therefore, defense enterprises have become unable to invest in expanding their production.

At times of the development of scientific and technological progress and the rising cost of production of military products, there is a tendency of simultaneous participation of several countries in this process. This fact allows reducing the expenditures of one country in such an expensive field. However, the internationalization of such processes requires state regulation. The possibility of the participation of foreign states in the production of military and dual-use goods must be regulated at the state level, as it is connected with the defense capabilities and security of our state. 
There are following effective forms of state regulation:

- stimulation of innovation activity, that is, introduction of the latest achievements of engineering and technology, obtained on the basis of scientific and technological developments, in the production of goods and services that meet the needs of the market and the development of the society as a whole,

- effective use of material and financial resources allocated to the military organization of the state;

- improvement of the existing economic mechanism, which allows increasing the efficiency of military expenditures under tight budget constraints.

Under conditions of a constant shortage of funds that the state can allocate for defense and other needs, the level of combat readiness of troops is becoming increasingly dependent on the effectiveness of using even insignificant resources. This confirms the growing role of militaryeconomic logistics in the military sphere, which ensures rational spending of allocated resources on achievement of the set goals.

A review of recent papers and dissertation research has not allowed revealing fundamental theoretical and methodological works where the results of the research on the production of military and dual-use items would be studied systematically and comprehensively.

We share the view of M.A. Saiensus, that "Logistics of sustainable development is designed to form the following main areas $[11$, p. 30]:

- minimization of costs associated with the inefficiency of the logistics process,

- efficient use of energy resources,

- efficient use of material and raw material resources,

- efficient use of available capacities (production, warehouse, transport),

- minimization of environmental impacts,

- development and introduction of innovative methods of management and organization of logistics processes".

The purpose of the research is to scientifically substantiate and prove the feasibility of using modern approaches to the use and production of dual-use products, which will help to optimize the resource support of the Armed Forces of Ukraine.

\section{RESEARCH RESULTS}

The condition of the domestic industry for the dual-use goods production makes a very complicated impression. It is clear without magnification that most cars, buses, cranes, loaders, tractors, bulldozers and other mechanical means on the roads of our country are foreign made. There is a similar situation at the enterprises of heavy and transport machine-building industry, instrumental, 
machine-tool, instrument-making and other factories. The production of various household electrical appliances, televisions, computers, etc. has been reduced sufficiently.

The Law of Ukraine "On State Control of International Transfers of Military and Dual-Use Goods" states that "dual-use goods are certain types of products, equipment, materials, software and technologies not specifically designed for military use, as well as services (technical assistance) connected with them, which, in addition to civilian use, can be utilized for military or terrorist purposes or for the development, production and usage of military goods, weapons of mass destruction, means of delivery of weapons being mentioned above or nuclear explosive devices, including certain types of nuclear materials, chemicals, bacteriological, biological and toxic substances, the list of which is determined by the Cabinet of Ministers of Ukraine " [2].

Thus, dual-use technologies are considered to be technologies as well as scientific and technical information that are used for civilian purposes, but can be applied for the production of weapons and military equipment, including weapons of mass destruction (chemical, biological, nuclear).

The history of dual-use technologies started with the era of nuclear physics, when it became apparent that the potential of the developed methods, on the one hand, opened up new horizons in energy industry and medicine, and on the other hand, it could lead to the creation of weapons of mass destruction with unprecedented and impressive power.

The development and implementation of new technologies is a key determinant of the country's position in the world. In such countries as the United States, Great Britain, Japan, France, Germany, it is considered that technology development should be viewed from the perspective of wider use in civilian and military spheres, and the development of scientific and technological potential is considered to be a common task of the national economy.

In Ukraine, science and engineering, technology and production have traditionally been valued for their importance in performing military tasks. But even in the Soviet period, the harmfulness of the imbalances in the economy towards the military sphere was realized and, as a result, a controlled conversion was conceived. It was assumed that advanced military technologies would be effective in the civilian sphere to the same degree. However, it worked well only in a relatively small group of technologies and only at some enterprises.

In general, in the period of restructuring, due to a number of reasons (including dramatic denationalization of property without any real increase in the investment activity of new owners), the high-tech sector of the Ukrainian economy suffered the most.

In today's conditions, regardless its economical capacity, a country is not able to cope with the development of all technologies that are of prime importance for its economic development. 
Therefore, a state should provide special support, first and foremost, to the production of "dual-use" equipment and technologies, which, as a rule, is science-based and expensive.

Dual-use technologies include technologies, used in the creation of weapons and military equipment, that can be used to create civilian products, as well as technologies related to civilian products potentially suitable for use in the production of military equipment.

Dual-use technologies have essential advantages over exclusively military and civilian technologies, which are as follows:

- they allow stimulating their development and reducing the implementation time, as well as the transformation of military and civilian technologies due to the rapid turnover of funds invested in dual technologies;

- they reduce the technological gap between the military and civilian sectors of the economy, which allows, if necessary, using the potential of the entire industry of the state in the interests of the military-industrial complex;

- they provide an opportunity to optimize and minimize the expenditures of the state budget and extra budgetary funds in support of scientific, technical and industrial potential, as well as the costs of production, taking into account dynamic environment;

- they reduce the military costs of creating a scientific and engineering product, that has a dual purpose, and allow to concentrate efforts on the development of exclusively military technologies in order to create new advanced samples of defensive and military equipment.

The analysis showed that there are serious problems that significantly impede the efficient production of new types of defensive and military equipment within the framework of the state defense order and the development of serial production of competitive dual-use products. In this respect, the following issues should be highlighted:

- $\quad$ rising prices for raw materials, energy, materials, semi-finished products and purchased products, which are not compensated by the introduction of resource-saving technologies and increase the growth of production costs;

- lowering of qualification of scientific and production personnel and increase in their average age, which significantly reduce the quality of dual-use products;

- fatigue and aging of key assets, poor status of scientific-production and material base, which are not advantageous to the latest technologies and do not ensure the fulfillment of the specified requirements to design documentation of manufactured dual-use products;

- shortage of investment resources, high loan interest rates and short-term loans that do not allow the implementation of high-tech projects with long payback periods; 
- inefficient state fiscal system and the lack of regulatory and legal framework, adequate to current economic environment, that regulates activities of legal entities and individuals in terms of the commercialization of dual technologies, providing production of dual-use goods;

- the absence of a competitive state technological exchange strategy that simultaneously provides both protection against unfair competition and the management of the process of transferring dual-use technologies to public sector enterprises for their commercial use, etc.

Dual-use technologies are quite complicated. On the one hand, they are based on scientific and technological achievements or inherent intellectual property, on the other hand - technologies must have standard suitability, and in other words, scientific and technological achievements must be brought to the level of the product to become a technology. As a rule, the second component in a financial plan is much wider, although the first one determines the technology intellectual potential. The transfer of the intellectual or innovative part of the technology allows us to determine the main point, and bringing it to the product is a necessary stage of manufacturing application. In the context of consumer promotion, such particular nature of technology requires effective management, including government control.

Nowadays, the necessity of the government support and control over technology transfer, first of all over the dual-use technologies, are especially important for Ukraine. Many research organizations, especially working for state defense order, having the highest scientific and technical potential and creating the world-class intellectual property, are not able to bring them to the level of high-technology, so they practically introduce a "semi-finished product" to the market. Consequently, the value of such products is low (lower than the fair value of the intellectual property object). In addition, the disparate arrangements of the national scientific institutions for the formation of contracts with ordering customers; their insufficient legal awareness allows customers to impose their disadvantageous conditions for enterprises in the defense industry, primarily in terms of protecting intellectual property and the financial matters of contracts.

There are examples of not bringing a noticeable economic benefit to the state, without control over the new technologies and "know-how" leakage abroad. This is especially true of "know-how", the transfer of which in most cases is carried out at prices significantly lower than world-wide, and often just for free. This is mainly explained by the complete disregarding of the accumulated scientific, technical and technological potentials, as well as utilization of a unique, expensive experimental base.

The consideration of the problem of transferring dual-use products will not be complete without analysis of its forms and directions. In this case, it is firstly necessary to determine that the concept of technology transfer within the framework of the investigated problem of dual-use 
technologies lies in the movement of technologies between nations, organizations, development and production stages, as well as application areas.

In fact, technology transfer occurs when technology passes from one economic unit to another (both within one state and between countries) or from one area of application to another. Primary research interest is attracted by the latest type of technology transfer - between the areas of application. It should be highlighted that such a transfer can be conducted without actual spatial movement of technology, for example, if the company has a diversified or conversion production.

At the same time, considering the dual-use product transfer as a political institution of international relations, the regulation of technology movement from one subject to another will play an equally important role. Moreover, the spheres of technology application in this case may not change (it means that the use of dual-use products by a subject in the civil (military) industry, can also be transmitted and received by the subject in the civil or military field.

Thus, it is possible to distinguish two transfer forms of dual use technologies:

- internal (within one economic unit),

- $\quad$ external (between units).

This way, for instance, a part of the technological process for developing a military laser can be adapted for creating a medical laser within a single laboratory. Since this process takes place within one unit, such a transfer is internal. If the laboratory passes the license of this technology to a commercial firm which will be responsible for developing a new commercial civil product, this is an example of an external transfer.

Also, the transfer of technology can take place inside and between economic units within one application area. Thus, the aforementioned laboratory can sell a component license to another company that intends to use this technology for military purposes. This kind of transfer is not a double use product transfer as it was defined above since the field of application has not changed.

There are two directions of the transfer of double use products: from the civilian sector to the military, and vice versa. Each direction has its own features and prerequisites for the transfer.

Thus, the transfer of double use products from the civilian sector to the military allows the use of technologies designed for civilian purposes in the defense industry, which can significantly reduce the prime cost of military products, and provides the opportunity to take advantage of the technological dynamism of the civilian production. In many countries, procurement agencies in the defense industry are developing their purchasing policies in the light of the above-mentioned opportunities. In particular, the policy of the US, French and German departments of defense in the area of double use products has been developed largely in the light of the aforementioned [12; 10]. In the last decade, we have also been able to observe the introduction of a more flexible procurement 
policy that includes mechanisms for the use of commercial products (Commercial-Off-The-Shelf (COTS)) in military systems [8].

At present, a considerable attention is paid to the problems of improving the system of management of intellectual property rights in the legal and economic sciences.

Book Four of the Civil Code of Ukraine [1] strengthened the protection of intellectual property rights, increased the effectiveness of measures aimed at raising liability for their violation, and harmonized domestic legislation with international law.

In order to implement the provisions of part IV of the Civil Code of Ukraine, a number of following normative legal acts were adopted: the Law of Ukraine No. 143-V "On State Regulation of Activities in the Field of Technology Transfer" dated September 14, 2006 [3], the Law of Ukraine No. 3687-XII "On Protection of Rights to Inventions and Utility Models" dated December 15, 1993 [4]; the Resolution of the Cabinet of Ministers of Ukraine No. 938 "Regulations on Representatives of Intellectual Property (Patent Attorneys)" dated August 27, 1997 [7] and many others.

At the same time, without diminishing the significance of the adopted normative legal acts, it should be noted that neither the science nor the legislation has created an integral concept of managing intellectual property rights for the development and creation of dual-use products in general, and especially at the expense of attracting private investment. Meanwhile, this kind of products conceals a potential danger, since it can be used not only in the civilian industries, but also for the production of weapons and military equipment.

The regulatory framework in this area of activity is very distinct and regulates mainly those relations, where one of the participants is the state.

Legislators pay considerable attention to export control over the implementation of foreign economic operations, the subject of which are controlled goods, intellectual property and technologies, by establishing their mandatory licensing. The main normative acts in this area are the following Laws of Ukraine: No. 959-XII "On Foreign Economic Activity" dated April 16, 1991 [5],No. 549-IV "On the State Control of International Transfers of the Military and Dual-Use Goods" dated February 20, 2003 [2], the Decree of the President of Ukraine No. 287/2015"On the decision of the National Security and Defense Council of Ukraine dated May 6, 2015, "On the Strategy of National Security of Ukraine" dated May 26, 2015[6]. These legislative acts establish a general procedure for the implementation of agreements covering the named products. At the same time, the state's interests in the development of dual-use products, which are financed at the expense of private investors, including foreign ones, are still outside the sphere of legal regulation.

We share the point of view of Ye.V. Krasnykov[9], who states that currently in Ukraine, at the legislative level, the issues related to the production of weapons and military equipment remain 
unresolved, namely, the basic principles of activity related to the production of military equipment have not been formulated; the authority of state and foreign customers as well as the entities of production have not been defined; the order of appointment and the main tasks of principal designers responsible for the creation of armaments and military equipment have not been worked out, the list of means of state regulation of the activities within the military-industrial complex has not been introduced; no provisions determining the procedure for the initiation and creation of military equipment are provided; the procedure of the development of weapons and military equipment by a foreign order is not specified; no measures for the organization of the production of weapons and military equipment, as well as designer's control of it at the stages of production and phasing out, have been stated.

In any case, the absence of a clear legislative mechanism for regulating relations connected with dual-use technologies and created by attracting funds from individuals and legal entities creates prerequisites for malpractice, does not promote the attraction of private capital, and most importantly - impedes the priority task of ensuring defense and security state. In the future, the concept is intended to provide legal regulation of the following issues:

- to define the goals, forms of implementation, priorities of the state policy in the use of the results of intellectual activity of military, special and dual use;

- to establish the features of the legal regime of the results of intellectual activity of military, special and dual use;

- determine the powers of the executive authorities that realize the rights of the state on the results of intellectual activity of military, special and dual use and perform the functions of accounting and registering control over the results of intellectual activities of military, special and dual use.

Thus, the high scientific and technical potential of the military-industrial complex in the field of dual-use technologies for solving the tasks of modernizing the enterprises of the civil sector of the economy is currently unrealized, resulting in the fact that funds spent on research and design work are not returned to the state budget. The main reasons for underachievement in implementing such potential are as follows:

- lack of financial assets to bring the dual-use technology to the level of the finished product;

- lack of a complete legal and regulatory framework regulating the actions of legal entities and individuals in terms of commercialization of dual-use technologies; this creates the preconditions for the fact that enterprises of the military-industrial complex practically completely deviate from the implementation of the intellectual property protection regulations, established in the course of execution of the defense order; 
- lack of state regulation and management of the process of transferring (sharing) technologies of the military-industrial complex, first of all dual-use technologies, to enterprises of the public sector for their commercial use;

- low competitiveness of the enterprises of the defense industry in the market of high technologies in terms of their ability to use the intellectual property rights provided by the legislation, in particular, for restricting access of their competitors to advanced technical solutions;

- absence of the well-balanced patent and licensing policy of the enterprises of the militaryindustrial complex, which often leads either to the disclosure of technology at an early stage of cooperation, or to the low financial and economic efficiency of the concluded contracts due to the inability to prepare the technology for commercialization according to standards adopted in the developed industrialized countries;

- absence of the necessary specialists at the enterprises of the military-industrial complex for ensuring the legal protection of exclusive rights on the results of scientific and technical activities;

- lack of competitive strategy of technological exchange at the enterprises of the military-industrial complex, which simultaneously provides both protection against unfair competition and acceptable financial and economic efficiency of the project.

Therefore, under modern conditions of defense industry reform it is extremely important to use elements of military technology for civil purposes. Since dual-use technology is a significant factor in the development of the industrial sector.

\section{CONCLUSIONS}

Thus, the author defines dual-use technology as a technology that is used or potentially can be used both for military and civilian purposes. In this definition it is significant to focus on one point which is important in the practice of assigning specific technologies to this category. This is a potential opportunity for simultaneous use of the technology for military and civilian purposes. So, the hypothetical application of civilian technology in the military sector, or, conversely, allows assigning it to dual-use technology.

Dual-use technologies and their transfer are quite a new institution in international relations. At the same time, under the circumstances of the ever-changing international political situation, it is possible to observe changing their role and place in the system of political instruments. This fact, in the further process, creates the preconditions for deeper research of the transfer of dual-use products, their forms and mechanisms, since the need for their more detailed international and legal regulation is constantly increasing. 
Producing dual-use items can stimulate their development and reduce the period of their introduction to civilian production. In addition, the technological gap between the military and civilian sectors of the economy decreases and this allows:

- using the potential of the entire industry of the state for the defensive purposes if necessary and under certain conditions,

- optimizing and minimize the expenditures of the state budget for the development of scientific, technical and industrial potential,

- reducing the cost of making a scientific and technological achievements of dual-use products and, thus, focus on the development of defensive technologies that provide the creation of fundamentally new samples of defensive and military equipment.

Thus, today the specific character of the situation in production of dual-use items in Ukraine is as follows: our country still has separate technological institutions, research and production base and qualified personnel that can develop and manufacture dual-use scientific and technical products.

\section{REFERENCES}

[1] CABINET OF Ministers of UKRAine. (2002).Regulations on Representatives of Intellectual Property (Patent Attorneys). Ukraine: Cabinet of Ministers of Ukraine. Document 938-97-п. (19.08.2002).

[2] GANSLER, J. S., \& LUCYSHYN, W. (2008). Commercial-off-the-shelf (cots): Doing it right (No. UMD-AM08-129). MARYLAND UNIV COLLEGE PARK CENTER FOR PUBLIC POLICY AND PRIVATE ENTERPRISE.

[3] KRASNYKOV, YE.V. (2018). ShliakhyvdoskonalenniazakonodavstvaUkraiiny u sferiviiskovotekhnichnohospivrobitnytstva $\mathrm{z}$ inozemnymyderzhavamy. Ways of improvement of the legislation of Ukraine in the sphere of military-technical cooperation with foreign countries. Theory and practice of public administration, 1(60), 1-5. (http://www.kbuapa.kharkov.ua/e-book/tpdu/2018-1/doc/5/02.pdf)

[4] Perani, G., \& Di Politica Internazionale, C. C. S. (1997). Military technologiesand commercial applications: Public policies in NATO countries. Rome, centroStudiPoliticaInternazionale.

[5] SAIENSUS, M.A. (2018). Osnovninapriamystaloiilohistyky: vymirvplyvunanavkolyshnieseredovyshche. Main directions of sustainable logistics: the measurement of the impact on the environment. Vchenizapysky TNU imeni V.I. Vernadskoho. SeriiaEkonomika I Upravlinnia, 4, V. 29(68), 2-33.

[6] The Civil Code of Ukraine. (2019). Document 435-IV. (4.02.2019).

[7] The DeCree of the President of Ukraine. (2015). On the decision of the National Security and Defense Council of Ukraine dated May 6, 2015. On the Strategy of National Security of Ukraine. Ukraine: The Decree of the President of Ukraine - 26.05.2015. No. 287/2015

[8] The Law of Ukraine. (2012). On Protection of Rights to Inventions and Utility Models. Document 3687XII. (5.12.2012).

[9] The LaW of Ukraine. (2015). On State Regulation of Activities in the Field of Technology Transfer. Document 143-V. (9.12.2015).

[10] The Law of Ukraine. (2019). On Foreign Economic Activity. Document 959-XII. (7.02.2019). on the basis - 2473-VIII.

[11] The Law of Ukraine. (2019). On the State Control of International Transfers of the Military and Dual-Use Goods. Document 549-IV. (3.02.2019).

[12] STARKIN,S. V. (2007). O transformatsiioboronnoipromyshlennostiSShA[On the transformation of the US defense industry]. VestnikNizhegorodskogouniversitetaim. N. Y. Lobachevskogo, 6, 231-237. 